\title{
Autoradiographic Characterization and Localization of Quisqualate Binding Sites in Rat Brain Using the Antagonist

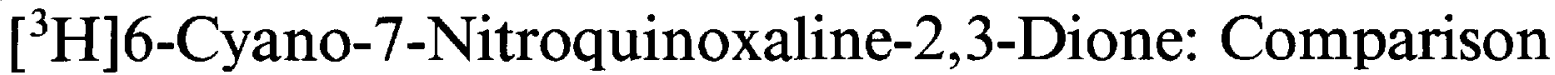 with $(R, S)-\left[{ }^{3} \mathrm{H}\right] \alpha$-Amino-3-Hydroxy-5-Methyl- 4-Isoxazolepropionic Acid Binding Sites
}

\author{
Elsebet $\varnothing$. Nielsen, Jørgen Drejer, *Jang-Ho J. Cha, *Anne B. Young, and Tage Honoré \\ Ferrosan Research Division, Soeborg, Denmark; and *Department of Neurology, \\ University of Michigan, Ann Arbor, Michigan, U.S.A.
}

\begin{abstract}
Using quantitative autoradiography, we have investigated the binding sites for the potent competitive non$N$-methyl-D-aspartate (non-NMDA) glutamate receptor antagonist $\left[{ }^{3} \mathrm{H}\right] 6$-cyano-7-nitro-quinoxaline-2,3-dione $\left(\left[{ }^{3} \mathrm{H}\right]\right.$ CNQX) in rat brain sections. $\left[{ }^{3} \mathrm{H}\right] \mathrm{CNQX}$ binding was regionally distributed, with the highest levels of binding present in hippocampus in the stratum radiatum of CA 1 , stratum lucidum of $\mathrm{CA} 3$, and molecular layer of dentate gyrus. Scatchard analysis of $\left[{ }^{3} \mathrm{H}\right] \mathrm{CNQX}$ binding in the cerebellar molecular layer revealed an apparent single binding site with a $K_{\mathrm{D}}=67 \pm 9.0 \mathrm{n} M$ and $B_{\max }=3.56 \pm 0.34 \mathrm{pmol} / \mathrm{mg}$ protein. In displacement studies, quisqualate, L-glutamate, and kainate also appeared to bind to a single class of sites. However, $(R, S)$ $\alpha$-amino-3-hydroxy-5-methyl-4-isoxazolepropionic acid (AMPA) displacement of $\left[{ }^{3} \mathbf{H}\right] \mathrm{CNQX}$ binding revealed two binding sites in the cerebellar molecular layer. Binding of [ $\left.{ }^{3} \mathrm{H}\right] \mathrm{AMPA}$ to quisqualate receptors in the presence of potassium thiocyanate produced curvilinear Scatchard plots.
\end{abstract}

The curves could be resolved into two binding sites with $K_{\mathrm{D} 1}$ $=9.0 \pm 3.5 \mathrm{nM}, B_{\max }=0.15 \pm 0.05 \mathrm{pmol} / \mathrm{mg}$ protein, $K_{\mathrm{D} 2}$ $=278 \pm 50 \mathrm{nM}$, and $B_{\max }=1.54 \pm 0.20 \mathrm{pmol} / \mathrm{mg}$ protein. The heterogeneous anatomical distribution of $\left[{ }^{3} \mathrm{H}\right] \mathrm{CNQX}$ binding sites correlated to the binding of $\mathrm{L}-\left[{ }^{3} \mathrm{H}\right]$ glutamate to quisqualate receptors and to sites labeled with $\left[{ }^{3} \mathrm{H}\right] \mathrm{AMPA}$. These results suggest that the non-NMDA glutamate receptor antagonist $\left[{ }^{3} \mathrm{H}\right] \mathrm{CNQX}$ binds with equal affinity to two states of quisqualate receptors which have different affinities for the agonist [ $\left.{ }^{3} \mathrm{H}\right]$ AMPA. Key Words: Glutamate receptorsQuisqualate- $(R, S)$ - $\alpha$-Amino-3-hydroxy-5-methyl-4-isoxazolepropionic acid-6-Cyano-7-nitroquinoxaline-2,3dione-Quantitative autoradiography. Nielsen E. $\varnothing$. et al. Autoradiographic characterization and localization of quisqualate binding sites in rat brain using the antagonist $\left[{ }^{3} \mathrm{H}\right] 6-$ cyano-7-nitroquinoxaline-2,3-dione: Comparison with $(R, S)$ $\left[{ }^{3} \mathrm{H}\right] \alpha$-amino-3-hydroxy-5-methyl-4-isoxazolepropionic acid binding sites. J. Neurochem. 54, 686-695 (1990).
L-Glutamate is the major excitatory neurotransmitter in the mammalian CNS (Watkins and Evans 1981; Foster and Fagg, 1984). Electrophysiological evidence indicates that the excitatory action of L-glutamate is mediated by at least three subtypes of receptors named according to the agonists $N$-methyl-Daspartate (NMDA), quisqualate, and kainate which preferentially excite them. The NMDA receptor subtype is well characterized, and both competitive (Davies et al., 1986) and noncompetitive (Anis et al.,
1983; Wong et al., 1986) NMDA receptor antagonists have been described. In contrast, studies of the nonNMDA receptors, the quisqualate and kainate receptors, have been limited by the lack of potent and selective antagonists.

In receptor binding studies the three receptor subtypes appear to be labeled directly by the NMDA antagonists $\left[{ }^{3} \mathrm{H}\right] 3-(2-c a r b o x y p i p e r a z i n-4-y 1)$ propyl-1phosphonic acid ([ $\left.\left.{ }^{3} \mathrm{H}\right] \mathrm{CPP}\right)$ (Murphy et al., 1987a) and cis- $\left[{ }^{3} \mathrm{H}\right] 4$-phosphonomethyl-2-piperidine carboxylic
Received January 17, 1989; revised manuscript received May 25, 1989; accepted July 25, 1989.

Address correspondence and reprint requests to Dr. E. Ø. Nielsen at Ferrosan Research Division, 5 Sydmarken, DK-2860 Soeborg, Denmark.

Abbreviations used: AMPA, $(R, S)$ - $\alpha$-amino-3-hydroxy-5-methyl- 4-isoxazolepropionic acid; CGS 19755, cis-4-phosphonomethyl-2piperidine carboxylic acid; CNQX, 6-cyano-7-nitro-quinoxaline-2,3dione; CPP, 3-(2-carboxypiperazin-4-yl)propyl-1-phosphonic acid; DNQX, 6,7-dinitro-quinoxaline-2,3-dione; $\mathrm{KSCN}$, potassium thiocyanate; NMDA, $N$-methyl-D-aspartic acid; PI, phosphoinositide; Tris-Ac, Tris-acetate. 
acid ( $\left[{ }^{3} \mathrm{H}\right] \mathrm{CGS}$ 19755) (Murphy et al., 1988), $\left[{ }^{3} \mathrm{H}\right]$ kainate (Monaghan and Cotman, 1982), and the quisqualate agonist $(R, S)-\left[{ }^{3} \mathrm{H}\right] \alpha$-amino-3-hydroxy-5methyl-4-isoxazolepropionic acid ([ $\left.\left.{ }^{3} \mathrm{H}\right] \mathrm{AMPA}\right)$ (Honoré et al., 1982; Honoré and Nielsen, 1985; Olsen et al., 1987; Murphy et al., 1987b), respectively. The anatomical distribution of the three glutamate receptor subtypes in rat brain sections can be imaged selectively using $\mathrm{L}-\left[{ }^{3} \mathrm{H}\right] \mathrm{glutamate}$ as radioligand and specific incubation conditions and competitors (Greenamyre et al., 1985). The quisqualate receptor appears to be labeled specifically by $\left[{ }^{3} \mathrm{H}\right] \mathrm{AMPA}$ (Monaghan et al., 1984; Rainbow et al., 1984; Nielsen et al., 1988). The kainate subtype can be selectively labeled by $\left[{ }^{3} \mathrm{H}\right]$ kainate (Monaghan and Cotman, 1982; Unnerstall and Wamsley, 1983).

Recently, two potent competitive non-NMDA receptor antagonists-6,7-dinitro-quinoxaline-2,3-dione (DNQX) and 6-cyano-7-nitro-quinoxaline-2,3-dione (CNQX) - have been developed (Honoré et al., 1988). DNQX and CNQX inhibit [ $\left.{ }^{3} \mathrm{H}\right] A M P A$ binding at submicromolar concentrations, have a fivefold weaker action at kainate receptors, have no effect on binding to other neurotransmitter receptors (Honoré et al., 1988; Honoré et al., 1989b), and are potent competitive antagonists of quisqualate- and kainate-induced $\gamma$ $\left[{ }^{3} \mathrm{H}\right]$ aminobutyric acid release from cultured mouse cortical neurones with weaker effects on NMDA responses (Drejer and Honoré, 1988). DNQX and CNQX also block responses to quisqualate- and kainate-induced ${ }^{22} \mathrm{Na}$ flux from striatal slices more effectively than responses to NMDA (Drejer and Honoré, 1988), and selectively block the excitatory action of quisqualate and kainate in spinal neurons with little or no effect on that of NMDA (Honoré et al., 1988; Fletcher et al., 1988). In rat hippocampal and neocortical slices, CNQX and DNQX block acidic amino acid-induced depolarizations and synaptic components mediated by non-NMDA receptors (Blake et al., 1988; Fletcher et al., 1988).

The purpose of the present study was to determine the location of binding sites for the non-NMDA receptor antagonist $\left[{ }^{3} \mathrm{H}\right] \mathrm{CNQX}$ within the mammalian brain and to establish the pharmacological relevance of these antagonist binding sites by making a comparison with the pharmacology and distribution of nonNMDA receptors labeled by the agonist $\left[{ }^{3} \mathrm{H}\right]$ AMPA. To achieve this an in vitro quantitative receptor autoradiographic technique for $\left[{ }^{3} \mathrm{H}\right] \mathrm{CNQX}$ has been developed using rat brain sections. Furthermore, the anatomical relationship between quisqualate-sensitive L$\left[{ }^{3} \mathrm{H}\right]$ glutamate, $\left[{ }^{3} \mathrm{H}\right] \mathrm{AMPA}$, and $\left[{ }^{3} \mathrm{H}\right] \mathrm{CNQX}$ binding is described.

\section{MATERIALS AND METHODS}

\section{Materials}

L- $\left[{ }^{3} \mathrm{H}\right]$ Glutamic acid (sp act 41.5 to $53 \mathrm{Ci} / \mathrm{mmol}$ ), $\left[{ }^{3} \mathrm{H}\right]$ AMPA $(24.5-27.6 \mathrm{Ci} / \mathrm{mmol})$, and $\left[{ }^{3} \mathrm{H}\right] \mathrm{kainic}$ acid $(60.0$
$\mathrm{Ci} / \mathrm{mmol}$ ) were obtained from New England Nuclear (Boston, MA, U.S.A. $)$ and $\left[{ }^{3} \mathrm{H}\right] \mathrm{CNQX}(5.47 \mathrm{Ci} / \mathrm{mmol})$ with a chemical purity $\geq 97 \%$ and a radiochemical purity $\geq 98 \%$ was synthesized by Chemsyn Science Laboratories (Lenexa, KA, U.S.A.). Nonradioactive CNQX was synthesized at Ferrosan Research Division. Nonradioactive AMPA and quisqualate were obtained from Research Biochemicals (Natick, MA, U.S.A.) All other chemicals were purchased from Sigma.

\section{Tissue preparation}

Male Wistar rats (175-225 g) were decapitated, and the brains quickly removed, mounted with Tissue-Tek embedding matrix on a specimen stage, and frozen under powdered dry ice. The frozen brains were cut into $20-\mu \mathrm{m}$ horizontal sections at $-15^{\circ} \mathrm{C}$ on a Leitz cryostat (Leitz, Wetzlar, F.R.G.) and thaw-mounted onto chrome alum/gelatin-subbed slides. Sections were stored for less than $24 \mathrm{~h}$ at $-20^{\circ} \mathrm{C}$. To remove endogenous glutamate, all sections underwent a wash for 30 min at $2{ }^{\circ} \mathrm{C}$ in either $50 \mathrm{mM}$ Tris- $\mathrm{HCl}$ buffer (Tris-HCl), $\mathrm{pH}$ 7.20 , or $50 \mathrm{mM}$ Tris-acetate buffer (Tris-Ac), pH 7.20. Sections were blown dry under a stream of room temperature air.

\section{Autoradiography}

A detailed description of the method for glutamate receptor autoradiography has been published by Greenamyre et al. (1984). In brief, in competition studies tissues were incubated for $45 \mathrm{~min}$ at $2^{\circ} \mathrm{C}$ in $50 \mathrm{mM}$ Tris- $\mathrm{HCl}+2.5 \mathrm{mMCaCl}$ with various competitors in the presence of $200 \mathrm{nM}$ L$\left[{ }^{3} \mathrm{H}\right]$ glutamate (sp act $7.3-8.2 \mathrm{Ci} / \mathrm{mmol}$ ) in a total volume of $8 \mathrm{ml}$. Nonspecific binding, defined as $\mathrm{L}-\left[{ }^{3} \mathrm{H}\right] \mathrm{glutamate}$ binding in the presence of $1 \mathrm{~m} M$ unlabeled glutamate, represented $<10 \%$ of the total binding of $\mathrm{L}-\left[{ }^{3} \mathrm{H}\right] \mathrm{glutamate}$.

For the purposes of this article, "quisqualate-sensitive L$\left[{ }^{3} \mathrm{H}\right]$ glutamate binding" is defined as the binding that is displaced by $2.5 \mu M$ quisqualate (Greenamyre et al., 1984; Cha et al., 1988, 1989). When quisqualate competition studies were performed in the presence of $100 \mu M$ NMDA the number of low-affinity quisqualate sites was selectively reduced without affecting the density of high-affinity sites (Greenamyre et al., 1985). For regional distribution studies, sections were incubated in $50 \mathrm{~m} M$ Tris- $\mathrm{HCl}+2.5 \mathrm{~m} M \mathrm{CaCl}_{2}$ and $100 \mu M$ NMDA.

In experiments examining the effects of $\mathrm{Ca}^{2+}$ and $\mathrm{Cl}^{-}$, these ions were added as acetate and Tris salts, respectively. Thiocyanate ions were added as potassium thiocyanate (KSCN). Nonspecific binding was determined under each ionic condition.

$\left[{ }^{3} \mathrm{H}\right] \mathrm{AMPA}$ binding was determined using identical methods previously used for measuring quisqualate receptors (Nielsen et al., 1988). Incubations were carried out in $20 \mathrm{nM}$ $\left[{ }^{3} \mathrm{H}\right] \mathrm{AMPA}$ and $50 \mathrm{~m} M$ Tris- $\mathrm{HCl}$ plus $2.5 \mathrm{mM} \mathrm{CaCl} 2(\mathrm{pH}$ 7.20) with or without $100 \mathrm{~m} M$ KSCN. Sections were incubated for $60 \mathrm{~min}$ at $2^{\circ} \mathrm{C}$. Nonspecific binding was determined in the presence of $1 \mathrm{mM}$ L-glutamate and represented $<5 \%$ of total binding in the presence of $\mathrm{KSCN}$. In the absence of $\mathrm{KSCN}$, the nonspecific binding represented $<15 \%$.

For $\left[{ }^{3} \mathrm{H}\right] \mathrm{CNQX}$ binding, the tissue was incubated for 45 $\min$ in $50 \mathrm{n} M\left[^{3} \mathrm{H}\right] \mathrm{CNQX}$ at $2^{\circ} \mathrm{C}$ in $50 \mathrm{~m} M$ Tris- $\mathrm{HCl}(\mathrm{pH}$ 7.20). Nonspecific binding was determined in the presence of $1 \mathrm{mM}$ L-glutamate and represented $<30 \%$ of the total binding of $\left[{ }^{3} \mathrm{H}\right] \mathrm{CNQX}$.

After the incubation, sections were rinsed quickly three times with cold buffer, then rinsed with cold $2.5 \%(\mathrm{vol} / \mathrm{vol})$ glutaraldehyde in acetone. Sections incubated with 
$\left[{ }^{3} \mathrm{H}\right] \mathrm{CNQX}$ were rinsed quickly three times with cold buffer only. Sections were blown dry with warm air. The rinse/ drying procedure took less than $10 \mathrm{~s}$.

$\left[{ }^{3} \mathrm{H}\right]$ Kainate binding $(10 \mathrm{n} M)$ was carried out at $2^{\circ} \mathrm{C}$ for $45 \mathrm{~min}$ in $50 \mathrm{mM}$ Tris-Ac (pH 7.20). Nonspecific binding was determined in the presence of $1 \mathrm{~m} M$ L-glutamate. Sections were rinsed three times for $1 \mathrm{~min}$ in ice-cold buffer and dried with warm air.

Dried sections were placed in x-ray cassettes with appropriate radioactive standards (Pan et al., 1983) and apposed to LKB Ultrofilm ${ }^{3} \mathrm{H}$ for the $\mathrm{L}-\left[{ }^{3} \mathrm{H}\right]$ glutamate studies. Calibrated Amersham microscales and Amersham $\left[{ }^{3} \mathrm{H}\right] \mathrm{Hyperfilm}$ were used for the $\left[{ }^{3} \mathrm{H}\right] \mathrm{AMPA},\left[{ }^{3} \mathrm{H}\right] \mathrm{CNQX}$, and $\left[{ }^{3} \mathrm{H}\right]$ kainate experiments. The film was exposed to the tissue sections for $12-14$ days at $4^{\circ} \mathrm{C}$, then developed in Kodak D19 developer, fixed, rinsed, and dried. For $\left[{ }^{3} \mathrm{H}\right]$ kainate the exposure time was 4 weeks. The optical densities of the resultant film images were determined using an Amersham RAS-R1000 image analyzer.

The radioactivity was determined by a computer-generated polynomial regression analysis which compared film densities produced by the tissue sections to those produced by the radioactive standards. All data presented were analyzed densitometrically from autoradiographic images. Anatomical areas were localized using the atlas of Paxinos and Watson (1982).

Photographs of autoradiograms were prepared from images digitized on the RAS-R 1000 video processing system.

$K_{\mathrm{D}}, B_{\max }$, and $K_{\mathrm{i}}$ values were generated by the Kinetic, EBDA, LIGAND, and Lowry program from Elsevier-Biosoft.

\section{RESULTS}

The molecular layer of the cerebellum is known to have the highest proportion of quisqualate-sensitive sites relative to total L- $\left[{ }^{3} \mathrm{H}\right]$ glutamate binding; $79 \%$ of $\mathrm{L}-\left[{ }^{3} \mathrm{H}\right]$ glutamate binding can be displaced by $2.5 \mu \mathrm{M}$ quisqualate (Cha et al., 1988). Only $\left[{ }^{3} \mathrm{H}\right] \mathrm{AMPA}$ and $\left[{ }^{3} \mathrm{H}\right] \mathrm{CNQX}$ binding data from cerebellar molecular layer are presented. However, these data are representative for the stratum radiatum of $\mathrm{CA} 1$, molecular layer of dentate gyrus, striatum, and the outer layers of cerebral cortex.

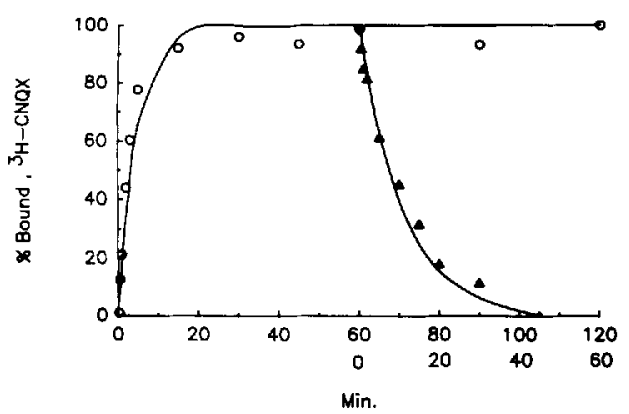

FIG. 1. Time course of association $(O)$ and dissociation $(\Delta)$ of $\left[{ }^{3} \mathrm{H}\right] \mathrm{CNQX}(50 \mathrm{nM})$ specific binding in the molecular layer of cerebellum. Binding shows rapid association and is readily reversible. Dissociation was affected by placing the slide into buffer without the radioligand. Each experiment was repeated three times on three separate animals with similar results.

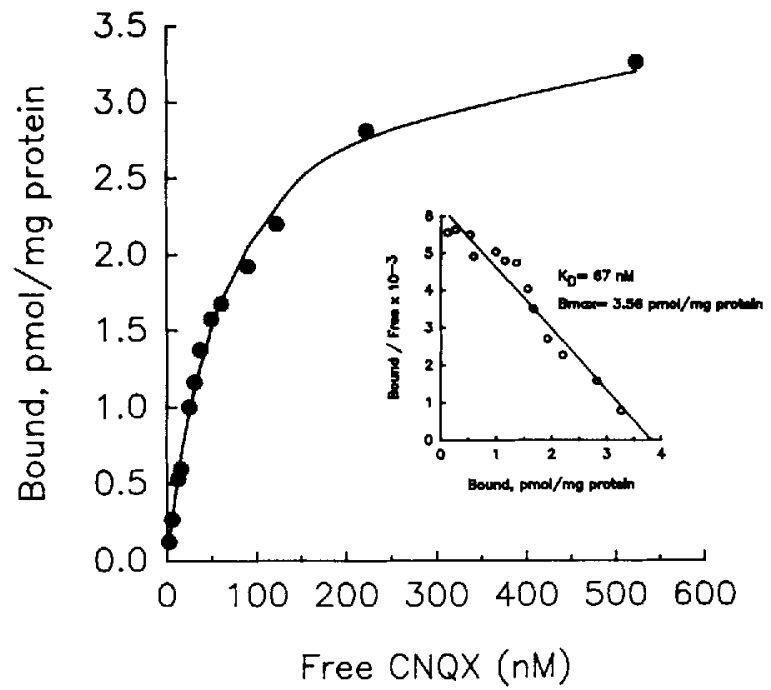

FIG. 2. Saturation and Scatchard (inset) plots of $\left[{ }^{3} \mathrm{H}\right] \mathrm{CNQX}$ binding in the molecular layer of the cerebellum. Ligand concentrations between $1 \mathrm{nM}$ and $1 \mu M$ were used. Autoradiography was performed as described in Materials and Methods and data were analyzed densitometrically. Each point represents specific binding. The experiment has been repeated four times in four animals with similar results.

\section{Binding parameters of $\left[{ }^{3} \mathrm{H}\right] \mathrm{CNQX}$ binding}

The binding of $50 \mathrm{n} M\left[{ }^{3} \mathrm{H}\right] \mathrm{CNQX}$ attained equilibrium after a $30-\mathrm{min}$ incubation at $2^{\circ} \mathrm{C}$ in the striatum and stratum radiatum of hippocampus whereas the molecular layer of cerebellum and cortex attained equilibrium after 15 min of incubation (Fig. 1) and remained stable for at least $2 \mathrm{~h}$. An incubation time of 45 min was chosen for future experiments. The "specific" binding accounted for $70 \%$ of the total binding. The best fit to the experimental values was monoexponential on-kinetics with $k_{\mathrm{obs}}$ of $0.20 \mathrm{~min}^{-1}$. This binding was fully reversible (Fig. 1) and the off-kinetics were apparently monoexponential with $k_{-1}$ of 0.085 $\mathrm{min}^{-1}$. Calculation of $k_{1}$ to $2.06 \times 10^{6} \mathrm{M}^{-1} \mathrm{~min}^{-1}$ gave a $K_{\mathrm{D}}$ of $41 \mathrm{n} M$.

$\left[{ }^{3} \mathrm{H}\right] \mathrm{CNQX}$ labeled high-affinity binding sites in rat brain in a saturable manner (Fig. 2). Scatchard analysis of saturation data $(1 \mathrm{n} M-1 \mu M)$ in the molecular layer of cerebellum indicated that $\left[{ }^{3} \mathrm{H}\right] \mathrm{CNQX}$ apparently bound to a single population of sites (Fig. 2) with $K_{\mathrm{D}}$ $=67 \pm 9.0 \mathrm{n} M$ and $B_{\max }=3.56 \pm 0.34 \mathrm{pmol} / \mathrm{mg}$ protein. $\left[{ }^{3} \mathrm{H}\right] \mathrm{CNQX}$ binding was increased by chloride ions (Table 1) whereas the effect of calcium was not significant. The presence of KSCN in all cases decreased the total binding (Table 1) without changing the relative regional distribution (data not shown).

\section{Inhibition of $\left[{ }^{3} \mathrm{H}\right] \mathrm{CNQX}$ binding}

Competition experiments were performed to evaluate the pharmacology of the sites labeled by $\left[{ }^{3} \mathrm{H}\right] \mathrm{CNQX}$. Displacement of $\left[{ }^{3} \mathrm{H}\right] \mathrm{CNQX}$ binding by L-glutamate in the cerebellar molecular layer gave a monophasic inhibition curve with $K_{\mathrm{i}}$ of $5.5 \pm 0.9 \mu \mathrm{M}$ (Fig. 3; Table 2). 
TABLE 1. Effects of calcium, chloride, and KSCN on quisqualate-sensitive $\left.L-l^{3} H\right]$ glutamate, $\left[{ }^{3} H\right] A M P A$, and $\Gamma^{3} H J C N Q X$ binding in the cerebellar molecular layer

\begin{tabular}{|c|c|c|c|}
\hline \multirow[b]{2}{*}{ Condition } & \multicolumn{3}{|c|}{ Bound ${ }^{3} \mathrm{H}$ ligand (pmol/mg of protein) } \\
\hline & $\begin{array}{c}\text { Quisqualate-sensitive } \\
\left.\text { L-[ }{ }^{3} \mathrm{H}\right] \text { glutamate binding }\end{array}$ & {$\left[{ }^{3} \mathrm{H}\right]$ AMPA binding } & {$\left[{ }^{3} \mathrm{H}\right] \mathrm{CNQX}$ binding ${ }^{a}$} \\
\hline $50 \mathrm{~m} M$ Tris-Ac & 0.89 & 0.94 & 0.71 \\
\hline $50 \mathrm{~m} M$ Tris-Ac $+100 \mathrm{~m} M$ KSCN & - & 3.67 & 0.45 \\
\hline $50 \mathrm{~m} M$ Tris- $\mathrm{HCl}$ & 2.70 & 1.15 & 1.19 \\
\hline $50 \mathrm{~m} M$ Tris $-\mathrm{HCl}+100 \mathrm{~m} M$ KSCN & - & 4.11 & 0.66 \\
\hline $50 \mathrm{~m} M$ Tris- $\mathrm{Ac}+2.5 \mathrm{~m} M \mathrm{CaAc}_{2}$ & 0.92 & 0.65 & 0.85 \\
\hline $50 \mathrm{~m} M$ Tris-Ac, $2.5 \mathrm{~m} M \mathrm{CaAc}_{2}+100 \mathrm{~m} M \mathrm{KSCN}$ & - & 3.33 & 0.61 \\
\hline $50 \mathrm{~m} M$ Tris- $\mathrm{HCl}+2.5 \mathrm{mM} \mathrm{CaCl}_{2}$ & 3.60 & 1.24 & 1.19 \\
\hline $50 \mathrm{~m} M$ Tris- $\mathrm{HCl}, 2.5 \mathrm{mM} \mathrm{CaCl}_{2}+100 \mathrm{mM} \mathrm{KSCN}$ & 3.40 & 3.60 & 0.68 \\
\hline
\end{tabular}

Values are the averages, from four rats, which varied $<20 \%$. Data for quisqualate-sensitive $\mathrm{L}-\left[{ }^{3} \mathrm{H}\right] \mathrm{glutamate}$ and $\left[{ }^{3} \mathrm{H}\right] \mathrm{AMPA}$ binding derive from Nielsen et al. (1988).

${ }^{a}\left[{ }^{3} \mathrm{H}\right] \mathrm{CNQX}$ binding was carried out at $45 \mathrm{n} M$ in $50 \mathrm{~m} M$ Tris- $\mathrm{HCl}$ as described in Materials and Methods.

A biphasic curve was obtained using AMPA as inhibitor of $\left[{ }^{3} \mathrm{H}\right] \mathrm{CNQX}$ binding. The curve could be resolved into two binding sites (Fig. 3). The $K_{\mathrm{i}}$ values of these sites were calculated to $15 \pm 7 \mathrm{n} M$ and $4.6 \pm 0.9$ $\mu M(p<0.001, F$ test, Table 2$)$. In the molecular layer of cerebellum, approximately $25 \%$ of the sites were of the high-affinity type and the remainder had low affinity for AMPA. Apparently, $\left[{ }^{3} \mathrm{H}\right] \mathrm{CNQX}$ labeled at least two distinct sites, which were indistinguishable in saturation binding studies, i.e., CNQX had the same affinity to the two sites, which could be resolved by AMPA.

Quisqualate and kainate inhibited the binding of $\left[{ }^{3} \mathrm{H}\right] \mathrm{CNQX}$ in the molecular layer of cerebellum with a $K_{\mathrm{i}}$ of $0.77 \pm 0.05 \mu M$ and $20 \pm 3 \mu M$, respectively (Table 2). No specific $\left[{ }^{3} \mathrm{H}\right] \mathrm{CNQX}$ binding remained in the presence of $100 \mu M$ of the above mentioned displacers. NMDA had very low affinity for the $\left[{ }^{3} \mathrm{H}\right] \mathrm{CNQX}$ binding site (Table 2 ).

$K_{\mathrm{i}}$ values in the molecular layer of cerebellum were essentially identical to those values obtained in other brain areas.

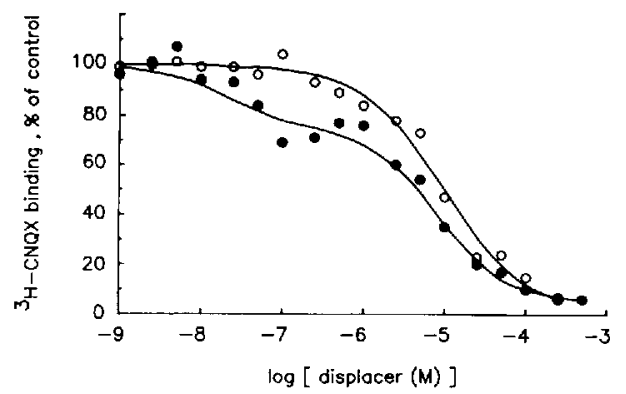

FIG. 3. Representative curves showing inhibition of $\left[{ }^{3} \mathrm{H}\right] \mathrm{CNQX}$ binding sites in the molecular layer of cerebellum by AMPA (O) and L-glutamate (O). The competition data for AMPA (O) was found to fit a two-site model significantly better than a one-site model ( $p$ $<0.001, F$ test). Each experiment was repeated three times on three separate animals with similar results.

\section{Regional distribution of $\left[^{3} \mathrm{H}\right] \mathrm{CNQX}$ binding}

$\left[{ }^{3} \mathrm{H}\right] \mathrm{CNQX}$ binding sites were distributed unevenly in rat brain sections. An example of the pattern of distribution is illustrated in Fig. 4. Note the high concentration of binding sites in the hippocampal formation, cerebral cortex, and cerebellar molecular layer with much lower levels in the granule cell layer of cerebellum and thalamus. Densitometric analysis of autoradiograms from serial sections obtained from four rats indicated that the highest concentration of specifically bound $\left[{ }^{3} \mathrm{H}\right] \mathrm{CNQX}$ occurred in the stratum radiatum of CA1. A summary of the mean data from 11 brain regions is shown in Table 3.

\section{Binding parameters of $\left[{ }^{3} \mathrm{H}\right] \mathrm{AMPA}$ binding}

$\left[{ }^{3} \mathrm{H}\right]$ AMPA labeled binding sites in rat brain in a saturable manner both in the absence and presence of KSCN (data not shown).

Saturation experiments were done in the absence and presence of $100 \mathrm{~m} M \mathrm{KSCN}$ to investigate the type of interaction between $\mathrm{SCN}^{-}$and the $\left[{ }^{3} \mathrm{H}\right] \mathrm{AMPA}$ binding sites. In the absence of $\mathrm{KSCN},\left[{ }^{3} \mathrm{H}\right] \mathrm{AMPA}$ binding ( $1 \mathrm{n} M-2 \mu M$ ) revealed linear Scatchard plots (Fig. 5) with $K_{\mathrm{D}}=143 \pm 29 \mathrm{n} M$ and $B_{\max }=0.32$

TABLE 2. Inhibition of $\left[{ }^{3} H\right] C N Q X$ binding sites in the molecular layer of cerebellum by various standard compounds

\begin{tabular}{lcc}
\hline Compound & $K_{\mathrm{i}}(\mu M)$ & $B_{\max }(\mathrm{pmol} / \mathrm{mg}$ protein $)$ \\
\hline AMPA & $0.015 \pm 0.007,4.6 \pm 0.9$ & $0.98 \pm 0.27,3.39 \pm 0.21$ \\
Quisqualate & $0.77 \pm 0.05$ & $2.69 \pm 0.16$ \\
L-Glutamate & $5.5 \pm 0.9$ & $4.20 \pm 0.14$ \\
Kainate & $20 \pm 3$ & $4.52 \pm 0.19$ \\
NMDA & $292 \pm 32$ & $3.38 \pm 0.12$ \\
\hline
\end{tabular}

Data represent the means \pm SEM of four experiments. At least 18 concentrations ( $1 \mathrm{n} M-500 \mu M$ ) of each inhibitor were used in each experiment. In the case of AMPA a two-site fit was significantly better $(p<0.001, F$ test $)$ than a one-site fit. 


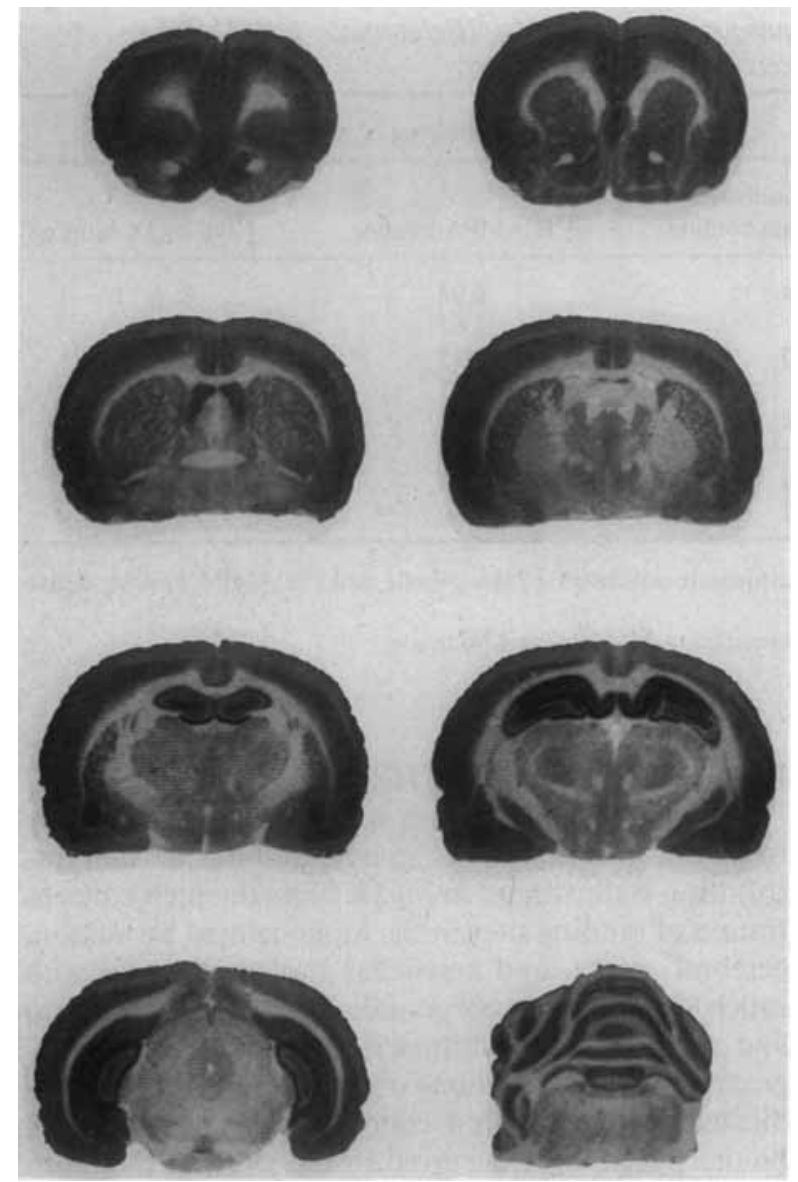

FIG. 4. Digitized images of $\left[{ }^{3} \mathrm{H}\right] \mathrm{CNQX}$ binding in rat brain coronal sections. The non-NMDA receptors were labeled by incubation with $50 \mathrm{nM}\left[{ }^{3} \mathrm{H}\right] \mathrm{CNQX}$ in Tris-HCl buffer for $45 \mathrm{~min}$ at $2^{\circ} \mathrm{C}$ as described in Materials and Methods.

$\pm 0.05 \mathrm{pmol} / \mathrm{mg}$ protein. In the presence of $\mathrm{KSCN}$, [ $\left.{ }^{3} \mathrm{H}\right]$ AMPA binding $(1 \mathrm{n} M-2 \mu M$ ) gave a curvilinear Scatchard plot (Fig. $5 ; p<0.001, F$ test) as compared to a linear fit. If it is assumed that the curvilinearity reflects multiplicity of binding sites the curves can be resolved into two binding sites with $K_{\mathrm{D} 1}=9.0 \pm 3.5$ $\mathrm{n} M, B_{\max }=0.15 \pm 0.05 \mathrm{pmol} / \mathrm{mg}$ protein, $K_{\mathrm{D} 2}=278$ $\pm 50 \mathrm{n} M, B_{\max }=1.54 \pm 0.20 \mathrm{pmol} / \mathrm{mg}$ protein. $\mathrm{KSCN}$ apparently increased both the affinity and the density of binding sites (Fig. 5).

Investigations of the pharmacological specificity of the $\left[{ }^{3} \mathrm{H}\right]$ AMPA binding site in the presence of KSCN revealed that quisqualate and AMPA were the most potent inhibitors (Table 4). Moderate inhibitors of $\left[{ }^{3} \mathrm{H}\right] \mathrm{AMPA}$ binding included CNQX and L-glutamate. Kainate was weakly active with an $\mathrm{IC}_{50}$ value of 4.9 $\mu M$, whereas NMDA was inactive at $100 \mu M$ (Table 4).

Comparison of the distribution of $\left[{ }^{3} \mathrm{H}\right] \mathrm{CNQX}$ binding sites with those labeled with $\mathrm{L}-\left[{ }^{3} \mathrm{H}\right] \mathrm{glutamate}$ and $\left.{ }^{3} \mathrm{H}\right] \mathrm{AMPA}$

The distributions of quisqualate-sensitive $\mathrm{L}-\left[{ }^{3} \mathrm{H}\right]-$ glutamate and $\left[{ }^{3} \mathrm{H}\right]$ AMPA sites have previously been shown (Greenamyre et al., 1985; Cha et al., 1988; Nielsen et al., 1988). Table 3 provides the distribution of L- $\left.{ }^{3} \mathrm{H}\right]$ glutamate sites (Nielsen et al., 1988) together with $\left[{ }^{3} \mathrm{H}\right] \mathrm{AMPA}$ and $\left[{ }^{3} \mathrm{H}\right] \mathrm{CNQX}$ binding obtained in the present study. To compare the data with the present values for $\left[{ }^{3} \mathrm{H}\right] \mathrm{CNQX}$ the density of binding in dentate gyrus in all studies has been designated $100 \%$. The density in other brain regions was then expressed as a percent of the dentate gyrus value. The distributions of $L-\left[{ }^{3} \mathrm{H}\right]$ glutamate, $\left[{ }^{3} \mathrm{H}\right] A M P A$, and $\left[{ }^{3} \mathrm{H}\right] \mathrm{CNQX}$ binding were very similar and the correlation coefficients between the binding of the three ${ }^{3} \mathrm{H}$ ligands are given in Table 5. Representative autoradiograms are shown in Fig. 6. By comparison the regional distribution of NMDA (labeled with $\mathrm{L}-\left[{ }^{3} \mathrm{H}\right]$ glutamate) and kainate (labeled with $\left[{ }^{3} \mathrm{H}\right]$ kainate) sites and correlation coefficients are shown in Tables 6 and 5, respectively.

\section{DISCUSSION}

Autoradiographic studies of excitatory amino acid receptors have provided important information concerning the localization and pharmacological properties of these receptors in mammalian brain (Monaghan et al., 1983, 1985; Greenamyre et al., 1984, 1985). As previously reported the total glutamate binding sites can be investigated by use of $\mathrm{L}-\left[{ }^{3} \mathrm{H}\right]$ glutamate (Greenamyre et al., 1983; Halpain et al., 1983; Monaghan et al., 1983). Unlabeled glutamate inhibits L- $\left[{ }^{3} \mathrm{H}\right]$ glutamate binding in a monophasic fashion, consistent with the possibility that glutamate interacts with a single class of receptors (Greenamyre et al., 1983, 1984, 1985; Halpain et al., 1983). Quisqualate displaces $\mathrm{L}-\left[{ }^{3} \mathrm{H}\right]$ glutamate binding in a biphasic manner, with the highand low-affinity components assumed to represent displacement of $L-\left[{ }^{3} \mathrm{H}\right]$ glutamate from quisqualate and NMDA receptors, respectively (Greenamyre et al., 1985; Foster and Fagg, 1987; Cha et al., 1988).

Binding of the competitive non-NMDA receptor antagonist $\left[{ }^{3} \mathrm{H}\right] \mathrm{CNQX}$ is stimulated by the presence of chloride whereas calcium is ineffective and $\mathrm{KSCN}$ has an inhibitory effect (Table 1). In contrast to L$\left[{ }^{3} \mathrm{H}\right]$ glutamate (Table 1, Cha et al., 1988; Nielsen et al., 1988) and [ ${ }^{3}$ H]AMPA (Table 1, Nielsen et al., 1988) binding, $\left[{ }^{3} \mathrm{H}\right] \mathrm{CNQX}$ binding is only minimally affected by the presence of chloride and KSCN (Table 1). The complex interaction between different ions and $\left[{ }^{3} \mathrm{H}\right]$ CNQX binding remains to be defined unambiguously and was not addressed in the present study.

$\left[{ }^{3} \mathrm{H}\right] \mathrm{AMPA}$ saturation experiments in the absence of KSCN showed that $\left[{ }^{3} \mathrm{H}\right] \mathrm{AMPA}$ binds to a single site. In the presence of KSCN the Scatchard plot was curvilinear, suggesting two binding sites (Fig. 5). $\mathrm{SCN}^{-}$ apparently increases the density of binding sites, and the density of the high-affinity $\left[{ }^{3} \mathrm{H}\right]$ AMPA binding site in the presence of $\mathrm{KSCN}$ is of the same magnitude as the total density of the sites obtained in the absence of KSCN. These results are in agreement with previous homogenate studies (Honoré and Drejer, 1988). The 


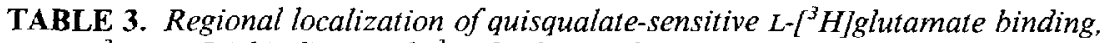
$\left.\Gamma^{3} \mathrm{H}\right] A M P A$ binding, and ${ }^{3} \mathrm{HJCNQX}$ binding in 11 regions of rat brain

\begin{tabular}{|c|c|c|c|}
\hline \multirow[b]{2}{*}{ Region } & \multicolumn{3}{|c|}{ Bound ${ }^{3} \mathrm{H}$ ligand (pmol/mg of protein) } \\
\hline & $\begin{array}{c}\text { Quisqualate-sensitive } \\
\mathrm{L}-\left[{ }^{3} \mathrm{H}\right] \text { glutamate binding }\end{array}$ & {$\left[{ }^{3} \mathrm{H}\right] \mathrm{AMPA}$ binding ${ }^{b}$} & {$\left[{ }^{3} \mathrm{H}\right] \mathrm{CNQX}$ binding ${ }^{c}$} \\
\hline \multicolumn{4}{|l|}{ Cerebral cortex } \\
\hline Somatosensory, layers I, II & $2.26 \pm 0.55(81.6 \%)$ & $1.84 \pm 0.30(85.2 \%)$ & $1.55 \pm 0.13(90.1 \%)$ \\
\hline Somatosensory, layers V, VI & $0.89 \pm 0.44(32.1 \%)$ & $0.92 \pm 0.15(52.5 \%)$ & $1.07 \pm 0.09(62.2 \%)$ \\
\hline Anterior cingulate & $1.68 \pm 0.44(60.6 \%)$ & $1.46 \pm 0.25(67.5 \%)$ & $1.37 \pm 0.12(79.7 \%)$ \\
\hline \multicolumn{4}{|l|}{ Hippocampal formation } \\
\hline Dentate gyrus & $2.77 \pm 0.49(=100 \%)$ & $2.16 \pm 0.32(=100 \%)$ & $1.72 \pm 0.15(=100 \%)$ \\
\hline Stratum radiatum of $\mathrm{CA} 1$ & $1.96 \pm 0.48(70.8 \%)$ & $2.44 \pm 0.23(112.9 \%)$ & $2.41 \pm 0.26(140.1 \%)$ \\
\hline $\mathrm{CA} 3$ & $1.40 \pm 0.42(50.5 \%)$ & $1.94 \pm 0.18(89.8 \%)$ & $1.88 \pm 0.18(109.3 \%)$ \\
\hline Striatum & $1.12 \pm 0.36(40.4 \%)$ & $0.93=0.10(43.2 \%)$ & $0.67 \pm 0.06(39.0 \%)$ \\
\hline Thalamus & $0.60 \pm 0.25(21.7 \%)$ & $0.39 \pm 0.04(18.1 \%)$ & $0.36 \pm 0.06(20.9 \%)$ \\
\hline Inferior colliculus & $0.75 \pm 0.21(27.1 \%)$ & $0.62 \pm 0.12(28.7 \%)$ & $0.24 \pm 0.06(14.0 \%)$ \\
\hline \multicolumn{4}{|l|}{ Cerebellum } \\
\hline Molecular layer & $1.73 \pm 0.32(62.5 \%)$ & $1.03 \pm 0.13(47.7 \%)$ & $1.12 \pm 0.14(65.1 \%)$ \\
\hline Granule cell layer & $0.50 \pm 0.20(18.1 \%)$ & $0.49 \pm 0.08(22.7 \%)$ & $0.37 \pm 0.07(21.5 \%)$ \\
\hline
\end{tabular}

Values are the averages \pm SEM in readings from four rats. Percentages represent binding as compared to binding in the dentate gyrus.

${ }^{a}$ Data for quisqualate-sensitive $\mathrm{L}-\left[{ }^{3} \mathrm{H}\right] \mathrm{gl}$ utamate binding derives from Nielsen et al. (1988).

${ }^{b}\left[{ }^{3} \mathrm{H}\right]$ AMPA binding was carried out at $50 \mathrm{n} M\left[{ }^{3} \mathrm{H}\right] \mathrm{AMPA}$ in $50 \mathrm{~m} M$ Tris- $\mathrm{HCl}, 2.5 \mathrm{~m} M \mathrm{CaCl}_{2}$, and $100 \mathrm{~m} M \mathrm{KSCN}$ as described in Materials and Methods.

${ }^{c}\left[{ }^{3} \mathrm{H}\right] \mathrm{CNQX}$ binding was carried out at $45 \mathrm{n} M\left[{ }^{3} \mathrm{H}\right] \mathrm{CNQX}$ in $50 \mathrm{~m} M$ Tris- $\mathrm{HCl}$ as described in Materials and Methods.

chaotropic ion KSCN increases the affinity of the binding, but it is unknown whether the density of the sites is also increased by KSCN or some sites just have very low affinity and fast off-rate in the absence of KSCN.

The issue of whether $\mathrm{KSCN}$ produces a redistribution of AMPA sites between two different affinity states or whether low- and high-affinity AMPA sites represent two separate receptor sites cannot be resolved with the present autoradiographic data. Recently, the complex relationship between $\left[{ }^{3} \mathrm{H}\right]$ AMPA binding and the pres-

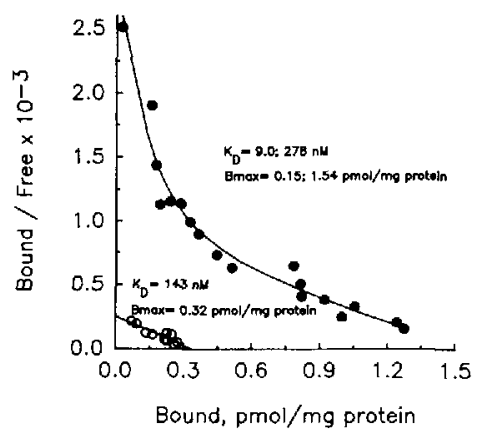

FIG. 5. Scatchard plot of $\left[{ }^{3} \mathrm{H}\right] \mathrm{AMPA}$ binding in the molecular layer of cerebellum in the absence $(O)$ and presence $(\bullet)$ of KSCN (100 $m M)$. $\left.{ }^{3} \mathrm{H}\right]$ AMPA binding was determined using concentrations from $1 \mathrm{nM}$ to $2 \mu \mathrm{M}$. Autoradiography was performed as described in Materials and Methods. In the presence of $\mathrm{SCN}^{-}$the two-site fit was significantly better than the one-site fit $(\rho<0.001, F$ test). The Scatchard plots are representative of four animals. ence of KSCN has been intensively investigated in homogenates of rat brain (Honoré and Drejer, 1988). Here it was found that $\left[{ }^{3} \mathrm{H}\right]$ AMPA binding showed curvilinear Scatchard plots that could not be explained by assuming binding to two separate binding sites or by considering it due to cooperative interaction. A more likely explanation was that the quisqualate receptors exist in two states, one with high and one with low affinity for $\left[{ }^{3} \mathrm{H}\right]$ AMPA. The equilibrium between the two states of quisqualate receptors can be shifted by KSCN toward the conformation with high affinity for AMPA (Honore and Drejer, 1988).

Saturation studies of $\left[{ }^{3} \mathrm{H}\right] \mathrm{CNQX}$ binding yielded linear Scatchard plots (Fig. 2). These results suggest

TABLE 4. Inhibition of $\left.{ }^{3} H\right] A M P A$ binding in the molecular layer of cerebellum by various standard compounds

\begin{tabular}{lc}
\hline Compound & $\mathrm{IC}_{50}(\mathrm{n} M)$ \\
\hline Quisqualate & $30 \pm 5$ \\
AMPA & $90 \pm 10$ \\
L-Glutamate & $510 \pm 95$ \\
CNQX & $520 \pm 90$ \\
Kainate & $4,900 \pm 730$ \\
NMDA & $>100,000$ \\
\hline
\end{tabular}

Five concentrations of each compound were used. Values are expressed as means \pm SEM of values from four rats. The assay was done in the presence of $100 \mathrm{mM} \mathrm{KSCN}$ using a final ligand concentration of $20 \mathrm{n} M$. 
TABLE 5. Correlation coefficients of binding to various glutamate receptor subtypes in rat brain

\begin{tabular}{lccc}
\hline & Quisqualate $^{a}$ & AMPA & CNQX \\
\hline Quisqualate & $-\bar{c}^{b}$ & $0.898^{b}$ & $0.775^{b}$ \\
AMPA & $0.898^{b}$ & $\overline{-}$ & $0.925^{b}$ \\
CNQX & $0.775^{b}$ & $0.925^{b}$ & - \\
Kainate & 0.099 & 0.404 & 0.402 \\
NMDA & $0.711^{b}$ & $0.819^{b}$ & $0.804^{b}$ \\
\hline
\end{tabular}

Comparison of the distribution (in $\mathrm{pmol} / \mathrm{mg}$ of protein) of the respective binding sites in 11 regions of rat brain has been done by use of the data presented in Tables 3 and 6 . Linear regression analysis yielded the listed correlation coefficients.

${ }^{a}$ Quisqualate-sensitive L-glutamate binding.

${ }^{b} p<0.001, t$ test.

that $\left.{ }^{3} \mathrm{H}\right] \mathrm{CNQX}$ binds to a single class of sites. Inhibition of $\left.{ }^{3} \mathrm{H}\right] \mathrm{CNQX}$ binding by L-glutamate is in accordance with a single site (Fig. 3; Table 2). Nevertheless, displacement of $\left.{ }^{3} \mathrm{H}\right] \mathrm{CNQX}$ binding by AMPA reveals a biphasic inhibition curve (Fig. 3; Table 2). About 25\% of the binding has high affinity for AMPA $\left(K_{\mathrm{i}}=15 \mathrm{n} M\right)$ and $75 \%$ has low affinity for AMPA $\left(K_{\mathrm{i}}\right.$ $=4.6 \mu M)$. The findings that AMPA gave biphasic inhibition curves of $\left[{ }^{3} \mathrm{H}\right] \mathrm{CNQX}$ binding, together with the linear Scatchard plot of $\left[{ }^{3} \mathrm{H}\right] \mathrm{CNQX}$ binding, suggests that $\left[{ }^{3} \mathrm{H}\right] \mathrm{CNQX}$ binds with the same affinity to the two states of the quisqualate receptor which have different affinities for $\left[{ }^{3} \mathrm{H}\right] \mathrm{AMPA}$. When quisqualate or kainate was used as an inhibitor of $\left[{ }^{3} \mathrm{H}\right] \mathrm{CNQX}$ binding only one site became apparent (Table 2).

The distribution of quisqualate-sensitive $\mathrm{L}-\left[{ }^{3} \mathrm{H}\right] \mathrm{glu}$ tamate binding was similar to but not identical with that of $\left[{ }^{3} \mathrm{H}\right]$ AMPA binding in rat brain (Table 3; Nielsen et al., 1988). However, the distribution of AMPA-displaceable quisqualate-sensitive $\mathrm{L}-\left[{ }^{3} \mathrm{H}\right] \mathrm{glu}$ - tamate binding in the presence of KSCN correlates well with that of $\left[{ }^{3} \mathrm{H}\right] A M P A$ binding, suggesting that $\left.{ }^{3} \mathrm{H}\right] \mathrm{AMPA}$ binds to a subclass of quisqualate receptors that are affected by the ionic environment (Nielsen et al., 1988).

Quisqualate has been shown to stimulate phosphoinositide (PI) metabolism in hippocampal slices (Nicoletti et al., 1986a; Palmer et al., 1988), and in cerebellar (Nicoletti et al., 1986b) and striatal cultures (Schmidt et al., 1987). Recently, it has been reported that AMPA neither stimulates PI turnover nor blocks the PI turnover stimulated by quisqualate in hippocampal slices (Schoepp and Johnson, 1988). Similar observations have been reported by Palmer et al. (1988) in the neonatal rat hippocampal slice. Furthermore, CNQX had no significant effect on quisqualate-induced inositol phosphate formation. The quisqualate receptor that stimulates PI metabolism may correspond to one of the two quisqualate-sensitive receptors described in Xenopus oocytes (Verdoorn and Dingledine, 1988). These data also suggest that there may be two subpopulations of quisqualate receptors: AMPA-sensitive and AMPA-insensitive or ionotropic and metabotropic receptors, respectively.

Despite the close similarity in the regional distribution of binding sites labeled by $\mathrm{L}-\left[{ }^{3} \mathrm{H}\right]$ glutamate, $\left[{ }^{3} \mathrm{H}\right] \mathrm{AMPA}$, and $\left[{ }^{3} \mathrm{H}\right] \mathrm{CNQX}$ (Table 5 ), some differences are observed in the percent of binding of these ligands in different brain areas (Table 3). A marked discrepancy between quisqualate-sensitive $\mathrm{L}-\left[{ }^{3} \mathrm{H}\right] \mathrm{glu}-$ tamate and $\left[{ }^{3} \mathrm{H}\right] \mathrm{AMPA} /\left[{ }^{3} \mathrm{H}\right] \mathrm{CNQX}$ binding in $\mathrm{CA} 1$ and CA3 of hippocampus is observed. Furthermore, $\left[{ }^{3} \mathrm{H}\right] \mathrm{CNQX}$ binding correlates better to $\left[{ }^{3} \mathrm{H}\right] \mathrm{AMPA}$ binding than to quisqualate-sensitive $\mathrm{L}-\left[{ }^{3} \mathrm{H}\right]$ glutamate binding (Table 5). A possible explanation may be that quisqualate-sensitive $\mathrm{L}-\left[{ }^{3} \mathrm{H}\right]$ glutamate binding repre-

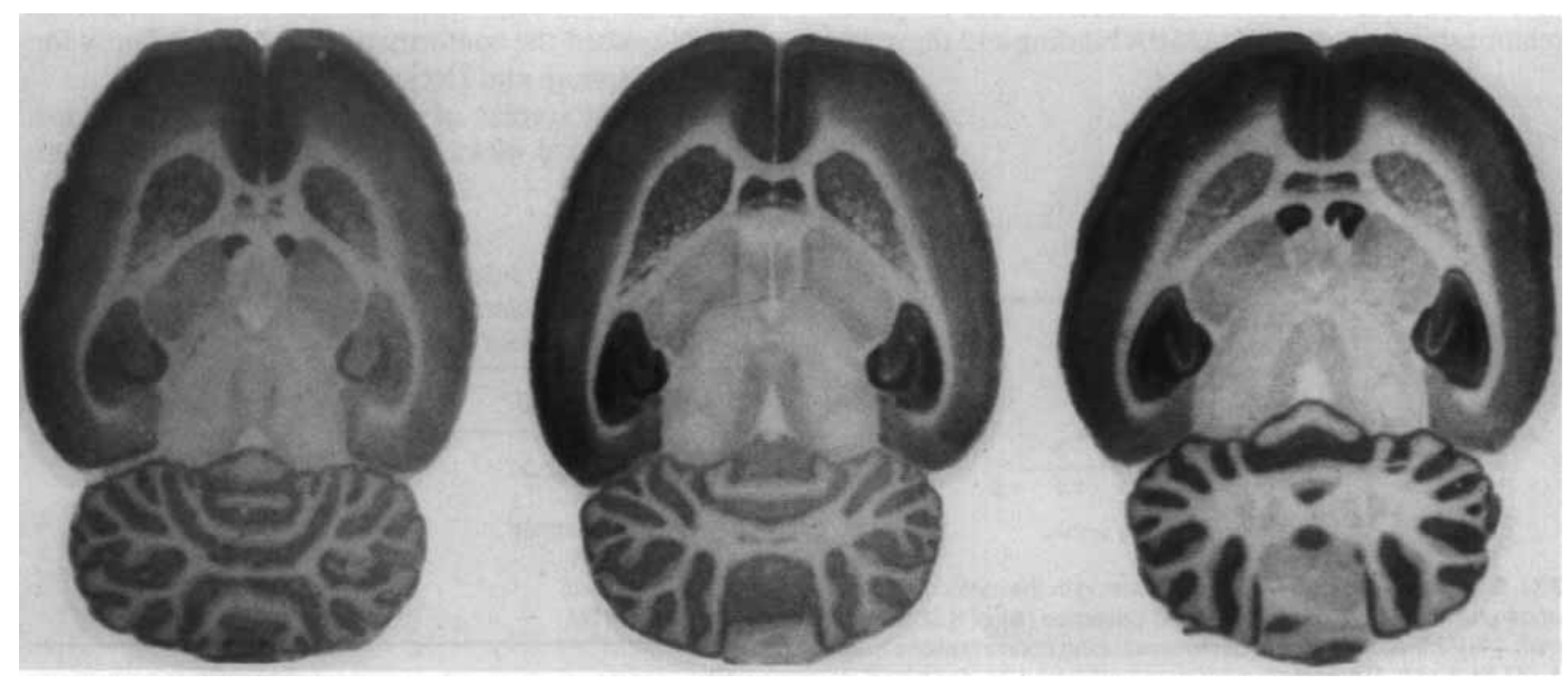

FIG. 6. Computer-generated images of autoradiograms of quisqualate-sensitive $L-\left[{ }^{3} \mathrm{H}\right]$ glutarnate $(200 \mathrm{nM})$ binding in $50 \mathrm{mM}$ Tris- $\mathrm{HCl}+2.5$ $\mathrm{mM} \mathrm{CaCl} \mathrm{Cl}_{2}+100 \mu \mathrm{M}$ NMDA (left), $\left.{ }^{3} \mathrm{H}\right] \mathrm{AMPA}\left(25 \mathrm{nM}\right.$ ) binding in $50 \mathrm{mM}$ Tris- $\mathrm{HCl}+2.5 \mathrm{mM} \mathrm{CaCl}+100 \mathrm{mM} \mathrm{KSCN}$ (middle), and [ $\left.{ }^{3} \mathrm{H}\right] \mathrm{CNQX}$ $(50 \mathrm{nM}$ ) binding in $50 \mathrm{mM}$ Tris-HCl (right). The results are representative of findings in four different rats. 
TABLE 6. Regional localization of NMDA-sensitive $\left.L-I^{3} H\right]$ glutamate binding and $\left.{ }^{3} \mathrm{H}\right]$ kainate binding in 11 regions of rat brain

\begin{tabular}{|c|c|c|}
\hline \multirow[b]{2}{*}{ Region } & \multicolumn{2}{|c|}{ Bound ${ }^{3} \mathrm{H}$ ligand (pmol/mg of protein) } \\
\hline & $\begin{array}{c}\text { NMDA-sensitive } \\
\mathrm{L}-\left[{ }^{3} \mathrm{H}\right] \text { glutamate binding }\end{array}$ & {$\left[{ }^{3} \mathrm{H}\right]$ Kainate binding ${ }^{b}$} \\
\hline \multicolumn{3}{|l|}{ Cerebral cortex } \\
\hline Somatosensory, layers I, II & $2.16 \pm 0.38(87 \%)$ & $0.019 \pm 0.004(76 \%)$ \\
\hline Somatosensory, layers V, VI & $1.04 \pm 0.26(42 \%)$ & $0.025 \pm 0.006(100 \%)$ \\
\hline Anterior cingulate & $1.83 \pm 0.47(74 \%)$ & $0.024 \pm 0.003(96 \%)$ \\
\hline \multicolumn{3}{|l|}{ Hippocampal formation } \\
\hline Dentate gyrus & $2.47 \pm 0.25(=100 \%)$ & $0.025 \pm 0.004(=100 \%)$ \\
\hline Stratum radiatum of CA1 & $3.24 \pm 0.37(131 \%)$ & $0.015 \pm 0.003(60 \%)$ \\
\hline $\mathrm{CA} 3$ & $1.06 \pm 0.17(43 \%)$ & $0.065 \pm 0.010(260 \%)$ \\
\hline Striatum & $0.70 \pm 0.16(28 \%)$ & $0.030 \pm 0.005(120 \%)$ \\
\hline Thalamus & $0.65 \pm 0.18(26 \%)$ & $0.006 \pm 0.001(24 \%)$ \\
\hline Inferior colliculus & $0.24 \pm 0.07(10 \%)$ & $0.003 \pm 0.001(12 \%)$ \\
\hline \multicolumn{3}{|l|}{ Cerebellum } \\
\hline Molecular layer & ND & $0.008 \pm 0.003(32 \%)$ \\
\hline Granule cell layer & $0.63 \pm 0.1(26 \%)$ & $0.025 \pm 0.007(100 \%)$ \\
\hline
\end{tabular}

sents binding to all quisqualate receptors, i.e., ionotropic and metabotropic, whereas $\left[{ }^{3} \mathrm{H}\right] \mathrm{CNQX}$ and $\left[{ }^{3} \mathrm{H}\right] \mathrm{AMPA}$ bind only to a portion of the quisqualate receptors. The ratio between AMPA-sensitive and AMPA-insensitive quisqualate receptors might be different in different brain areas.

Electrophysiological studies have shown that CNQX selectively blocks the excitatory action of both quisqualate and kainate on spinal neurons with little or no effect on that of NMDA (Honore et al., 1988). The relatively high densities of $\left[{ }^{3} \mathrm{H}\right] \mathrm{CNQX}$ binding in $\mathrm{CA} 3$ of hippocampus, inner layers of cerebral cortex, and anterior cingulate cortex (Table 3 ) might be explained by binding of $\left[{ }^{3} \mathrm{H}\right] \mathrm{CNQX}$ to kainate receptors as these areas are reported to be high in $\left[{ }^{3} \mathrm{H}\right]$ kainate binding (Monaghan and Cotman, 1982). However, monophasic inhibition curves were observed when $\left[{ }^{3} \mathrm{H}\right] \mathrm{CNQX}$ binding in $\mathrm{CA} 3$, inner layers of cerebral cortex, and anterior cingulate cortex was displaced by kainate, and $K_{\mathrm{i}}$ values (data not shown) similar to the $K_{\mathrm{i}}$ value obtained in the cerebellar molecular layer (Table 2) were observed. Second, opposite to $\left[{ }^{3} \mathrm{H}\right]$ kainate binding where the high-affinity site was inhibited by calcium (Monaghan et al., 1986), $\left[{ }^{3} \mathrm{H}\right] \mathrm{CNQX}$ binding was not affected by calcium (Table 1). Third, the molecular target size of the $\left[{ }^{3} \mathrm{H}\right] \mathrm{CNQX}$ binding site has been found to be different from the high-affinity $\left[{ }^{3} \mathrm{H}\right]$ kainate binding site, but equal to the low-affinity $\left[{ }^{3} \mathrm{H}\right] \mathrm{kainate}$ and $\left[{ }^{3}\right.$ H] AMPA sites (Honoré et al., 1989a). These results suggest that the $\left[{ }^{3} \mathrm{H}\right] \mathrm{CNQX}$ binding site is different from the high-affinity calcium-sensitive $\left[{ }^{3} \mathrm{H}\right]$ kainate binding site, but may be identical to the low-affinity $\left[{ }^{3} \mathrm{H}\right]$ kainate site (= quisqualate receptors) (Greenamyre et al., 1985). Consequently, the kainate-induced effects which can be antagonized by CNQX may not be mediated via the high-affinity kainate site, but rather via the low-affinity kainate site.

The distribution of $\mathrm{L}-\left[{ }^{3} \mathrm{H}\right]$ glutamate binding to NMDA sites (Table 6; Maragos et al., 1988) correlates with that of quisqualate-sensitive $\mathrm{L}-\left[{ }^{3} \mathrm{H}\right]$ glutamate, $\left[{ }^{3} \mathrm{H}\right] \mathrm{AMPA}$, and $\left[{ }^{3} \mathrm{H}\right] \mathrm{CNQX}$ binding (Table 5). This correlation might be explained by colocalization of NMDA and quisqualate receptors in most brain regions. Regional differences between the anatomical localization of NMDA and quisqualate sites were seen only in hippocampus and cerebellum (Tables 3 and 6).

Even though the binding of $\left[{ }^{3} \mathrm{H}\right] \mathrm{CNQX}$ and $\left[{ }^{3} \mathrm{H}\right]$ AMPA correlates with $\mathrm{L}-\left[{ }^{3} \mathrm{H}\right]$ glutamate binding to NMDA sites (Table 5), the binding is unlikely to be to NMDA sites, because quisqualate has a 300- and $>3,000$-fold higher affinity in the cerebellar molecular layer for $\left[{ }^{3} \mathrm{H}\right] \mathrm{CNQX}$ and $\left[{ }^{3} \mathrm{H}\right] \mathrm{AMPA}$ binding, respectively as compared to NMDA (Tables 2 and 4). The higher affinity of quisqualate relative to NMDA for the two ligands is consistent in different brain areas.

Furthermore, $\left[{ }^{3} \mathrm{H}\right] \mathrm{CNQX}$ binding to glycine receptors can be excluded, as neither glycine nor D-serine inhibits $\left[{ }^{3} \mathrm{H}\right] \mathrm{CNQX}$ binding to rat cortical membranes (Honoré et al., 1989a). 
In summary, the anatomical distribution and pharmacological characteristics of $\left[{ }^{3} \mathrm{H}\right] \mathrm{AMPA}$ and $\left[{ }^{3} \mathrm{H}\right]$ CNQX binding suggest binding to quisqualate receptors.

Acknowledgment: The expert technical assistance by Marianne L. Jacobsen is gratefully acknowledged. Furthermore, we appreciate the collaboration with Squibb Institute for Medical Research, Princeton, NJ, U.S.A.

\section{REFERENCES}

Anis N. A., Berry S. C., Burton N. R., and Lodge D. (1983) The dissociative anaesthetics, ketamine and phencyclidine, selectively reduce excitation of central mammalian neurones by $N$-methylD-aspartate. Br. J. Pharmacol. 79, 565-575.

Blake J. F., Brown M. W., and Collingridge G. L. (1988) CNQX blocks acidic amino acid induced depolarizations and synaptic components mediated by non-NMDA receptors in rat hippocampal slices. Neurosci. Lett. 89, 182-186.

Cha J. J., Greenamyre J. T., Nielsen E. Ø., Penney J. B., and Young A. B. (1988) Properties of quisqualate-sensitive L- $\left[{ }^{3} \mathrm{H}\right]-$ glutamate binding sites in rat brain as determined by quantitative autoradiography. $J$. Neurochem. 51, 469-478.

Cha J. J., Hollingworth Z. R., Greenamyre J. T., and Young A. B. (1989) Contamination of commercially available quisqualic acid by glutamic acid and aspartic acid. J. Neurosci. Methods 27, $143-148$

Davies J., Evans R. H., Herrling P. L., Jones A. W., Olverman H. J., Pook P., and Watkins J. C. (1986) CPP, a new potent and selective NMDA antagonist. Depression of central neuron responses, affinity for $\left[{ }^{3} \mathrm{H}\right] \mathrm{D}-\mathrm{AP} 5$ binding sites on brain membranes and anticonvulsant activity. Brain Res. 382, 169-173.

Drejer J. and Honoré T. (1988) New quinoxalinediones show potent antagonism of quisqualate responses in cultured mouse cortical neurones. Neurosci. Lett. 87, 104-108.

Fletcher E. J., Martin D., Aram J. A., Lodge D., and Honoré T. (1988) Quinoxalinediones selectively block quisqualate and kainate receptors and synaptic events in rat neocortex and hippocampus and frog spinal cord in vitro. Br. J. Pharmacol. 95, 585-597.

Foster A. C. and Fagg G. E. (1984) Acidic amino acid binding sites in mammalian neuronal membranes: their characteristics and relationship to synaptic receptors. Brain Res. Rev. 7, 103-164.

Foster A. C. and Fagg G. E. (1987) Comparison of $L-\left[{ }^{3} H\right]$ glutamate, D- $\left[{ }^{3} \mathrm{H}\right]$ aspartate, DL- $\left[{ }^{3} \mathrm{H}\right] \mathrm{APS}$ and $\left[{ }^{3} \mathrm{H}\right] \mathrm{NMDA}$ as ligands for NMDA receptors in crude postsynaptic densities from rat brain. Eur. J. Pharmacol. 133, 291-300.

Greenamyre J. T., Young A. B., and Penney J. B. (1983) Quantitative autoradiography of $\mathrm{L}-\left[{ }^{3} \mathrm{H}\right] \mathrm{glutamate}$ binding to rat brain. $\mathrm{Neu}$ rosci. Lett. 37, 155-160.

Greenamyre J. T., Young A. B., and Penney J. B. (1984) Quantitative autoradiographic distribution of $\mathrm{L}-\left[{ }^{3} \mathrm{H}\right]$ glutamate-binding sites in rat central nervous system. $J$. Neurosci. 4, 2133-2144.

Greenamyre J. T., Olson J. M. M., Penney J. B., and Young A. B. (1985) Autoradiographic characterization of $N$-methyl-D-aspartate-, quisqualate- and kainate-sensitive glutamate binding sites. J. Pharmacol. Exp. Ther. 233, 254-263.

Halpain S., Parsons P., and Rainbow T. C. (1983) Tritium-film autoradiography of sodium-independent glutamate binding sites in rat brain. Eur. J. Pharmacol. 86, 313-314.

Honoré T. and Drejer J. (1988) Chaotropic ions affect the conformation of quisqualate receptors in rat cortical membranes. $J$. Neurochem. 51, 457-461.

Honoré T. and Nielsen M. (1985) Complex structure of quisqualatesensitive glutamate receptors in rat cortex. Neurosci. Lett. 54, $27-32$.
Honoré T., Lauridsen J., and Krogsgaard-Larsen P. (1982) The binding of $\left[{ }^{3} \mathrm{H}\right]$ AMPA, a structural analogue of glutamic acid, to rat brain membranes. $J$. Neurochem. 38, 173-178.

Honoré T., Davies S. N., Drejer J., Fletcher E. J., Jacobsen P., Lodge D., and Nielsen F. E. (1988) Quinoxalinediones: potent competitive non-NMDA glutamate receptor antagonists. Science 241, $701-703$

Honoré T., Drejer J., Nielsen E. Ø., and Nielsen M. (1989a) NonNMDA glutamate receptor antagonist ${ }^{3} \mathrm{H}-\mathrm{CNQX}$ binds with equal affinity to two agonist states of quisqualate receptors. Biochem. Pharmacol. (in press).

Honoré T., Drejer J., Nielsen E. Ø., Watkins J. C., Olverman H. J., and Nielsen M. (1989b) Molecular target size analyses of the NMDA-receptor complex in rat cortex. Eur. J. Pharmacol. Mol. Pharmacol. 172, 239-247.

Maragos W. F., Penney J. B., and Young A. B. (1988) Anatomic correlation of NMDA and ${ }^{3} \mathrm{H}-\mathrm{TCP}$-labeled receptors in rat brain. J. Neurosci. 8, 493-501.

Monaghan D. T. and Cotman C. W. (1982) The distribution of $\left[{ }^{3} \mathrm{H}\right]$ kainic acid binding sites in rat CNS as determined by autoradiography. Brain Res. 252, 91-100.

Monaghan D. T., Holets V. R., Toy D. W., and Cotman C. W. (1983) Anatomical distributions of four pharmacologically distinct ${ }^{3} \mathrm{H}$-L-glutamate binding sites. Nature 306, 176-179.

Monaghan D. T., Yao D., and Cotman C. W. (1984) Distribution of $\left[{ }^{3}\right.$ H]AMPA binding sites in rat brain as determined by quantitative autoradiography. Brain Res. 324, 160-164.

Monaghan D. T., Yao D., and Cotman C. W. (1985) L-[ $\left.{ }^{3} \mathrm{H}\right]$ Glutamate binds to kainate-, NMDA- and AMPA-sensitive binding sites: an autoradiographic analysis. Brain Res. 340, 378-383.

Monaghan D. T., Nguyen L., and Cotman C. W. (1986) The distribution of $\left[{ }^{3} \mathrm{H}\right]$ kainate binding sites in primate hippocampus is similar to the distribution of both $\mathrm{Ca}^{2+}$-sensitive and $\mathrm{Ca}^{2+}$-insensitive $\left[{ }^{3} \mathrm{H}\right] \mathrm{kainate}$ binding sites in rat hippocampus. Neurochem. Res. 11, 1073-1082.

Murphy D. E., Schneider J., Boehm C., Lehmann J., and Williams M. (1987a) Binding of [ $\left.{ }^{3} \mathrm{H}\right] 3$-(2-carboxypiperazin-4-yl)-propy]1-phosphonic acid to rat brain membranes: a selective, highaffinity ligand for $N$-methyl-D-aspartate receptors. $J$. Pharmacol. Exp. Ther. 240, 778-784.

Murphy D. E., Snowhill E. W., and Williams M. (1987b) Characterization of quisqualate recognition sites in rat brain tissue using DL- $\left.{ }^{3} \mathrm{H}\right] \alpha$-amino-3-hydroxy-5-methylisoxazole-4-propionic acid (AMPA) and a filtration assay. Neurochem. Res. 12, 775-782.

Murphy D. E., Hutchison A. J., Hurt S. D., Williams M., and Sills M. A. (1988) Characterization of the binding of $\left[{ }^{3} \mathrm{H}\right]-$ CGS 19755 : a novel $\mathrm{N}$-methyl-D-aspartate antagonist with nanomolar affinity in rat brain. Br. J. Pharmacol. 95, 932-938.

Nicoletti F., Jadarola M. J., Wroblewski J. T., and Costa E. (1986a) Excitatory amino acid recognition sites coupled with inositol phospholipid metabolism: developmental changes and interaction with $\alpha 1$-adrenoceptors. Proc. Natl. Acad. Sci. USA 83, 19311935.

Nicoletti F., Wroblewski J. T., Novelli A., Alho H., Guidotti A., and Costa E. (1986b) The activation of inositol phospholipid metabolism as a signal-transducing system for excitatory amino acids in primary cultures of cerebellar granule cells. J. Neurosci. 6, 1905-1911.

Nielsen E. Ø., Cha J. J., Honoré T., Penney J. B., and Young A. B. (1988) Thiocyanate stabilizes AMPA binding to the quisqualate receptor. Eur. J. Pharmacol. 157, 197-203.

Olsen R. W., Szamraj O., and Houser C. R. (1987) [ $\left.{ }^{3} \mathrm{H}\right]$ AMPA binding to glutamate receptor subpopulations in rat brain. Brain Res. 402, 243-254.

Palmer E., Monaghan D. T., and Cotman C. W. (1988) Glutamate receptors and phosphoinositide metabolism: stimulation via quisqualate receptors is inhibited by $N$-methyl-D-aspartate receptor activation. Mol. Brain Res. 4, 161-165.

Pan H. S., Frey K. F., Young A. B., and Penney J. B. (1983) Changes in $\left[{ }^{3} \mathrm{H}\right]$ muscimol binding in substantia nigra, entopeduncular 
nucleus, globus pallidus and thalamus after striatal lesions as determined by quantitative autoradiography. $J$. Neurosci. 3, 1189-1198.

Paxinos G. and Watson C. (1982) The Rat Brain in Stereotaxic Coordinates. Academic Press, New York.

Rainbow T. C., Wieczorek C. M., and Halpain S. (1984) Quantitative autoradiography of binding sites for $\left[{ }^{3} \mathrm{H}\right] \mathrm{AMPA}$, a structural analogue of glutamic acid, Brain Res. 309, 173-177.

Schmidt B. H., Weiss S., Sebben M., Kemp D. E., Bockaert J., and Sladeczek F. (1987) Dual action of excitatory amino acids on the metabolism of inositol phosphates in striatal neurons. $\mathrm{Mol}$. Pharmacol. 32, 364-368.

Schoepp D. D. and Johnson B. G. (1988) Excitatory amino acid agonist-antagonist interactions at 2-amino-4-phosphonobutyric acid-sensitive quisqualate receptors coupled to phosphoinositide hydrolysis in slices of rat hippocampus. $J$. Neurochem. $\mathbf{5 0}, 1605-$ 1613.

Unnerstall J. R. and Wamsley J. K. (1983) Autoradiographic localization of high-affinity $\left[{ }^{3} \mathrm{H}\right]$ kainic acid binding sites in the rat forebrain. Eur. J. Pharmacol. 86, 361-371.

Verdoorn T. A. and Dingledine R. (1988) Excitatory amino acid receptors expressed in Xenopus oocytes: agonist pharmacology. Mol. Pharmacol. 34, 298-307.

Watkins J. C. and Evans R. H. (1981) Excitatory amino acid transmitters. Annu. Rev. Pharmacol. Toxicol. 21, 165-204.

Wong E. H. F., Kemp J. A., Priestly T., Knight A. R., Woodruff G. N., and Iversen L. L. (1986) The anticonvulsant MK-801 is a potent $\mathrm{N}$-methyl-D-aspartate antagonist. Proc. Natl. Acad. Sci. USA 83, 7104-7108. 